\title{
Kia Manawaroa Kia Puawai: enduring Māori livelihoods
}

\author{
Nichola Harcourt ${ }^{1} \mathbb{D}$. Shaun Awatere ${ }^{1} \cdot$ Jade Hyslop $^{1} \cdot$ Yvonne Taura $^{1} \cdot$ Mahuru Wilcox $^{1} \cdot$ Lara Taylor $^{1} \cdot$ Jonno Rau $^{1}$. \\ Puke Timoti ${ }^{1}$
}

Received: 18 March 2021 / Accepted: 28 September 2021 / Published online: 17 October 2021

(c) The Author(s) 2021, corrected publication 2021

\begin{abstract}
Neoliberalism has failed us. Our waterways are contaminated, their mauri (life-force) has diminished; our economic growth is fast approaching environmental limits, almost 4000 of our indigenous plant and animal species are currently threatened with or at risk of extinction, and our biodiversity has declined significantly. Increasingly stringent regulations are being rolled out by policy makers to protect natural systems, but these are framed by Eurocentric measures and concepts. If we are to achieve our vision to improve the health of te taiao (the environment) and our people, we need to change the way that people interact with their environment from a position of extractive resource use to one of reciprocal exchange. Te Ao Māori (the Māori world view) thinking offers us a pathway forward to achieving sustainable livelihoods that enable both the natural world and humans to prosper. In this paper, we showcase the operationalisation of He Waka Taurua, a framework for collaborative partnership based on the dual elevation of both Te Ao Māori and western science knowledge systems, through a Māori agribusiness case study.
\end{abstract}

Keywords Mātauranga Māori · Co-production $\cdot$ Collaboration $\cdot$ Kaitiakitanga $\cdot$ Agribusiness $\cdot$ Indigenous knowledge

\section{Introduction}

Handled by Kirsten Maclean, CSIRO, Australia.

Nichola Harcourt

harcourtn@landcareresearch.co.nz

Shaun Awatere

awateres@landcareresearch.co.nz

Jade Hyslop

hyslopj@landcareresearch.co.nz

Yvonne Taura

tauray@landcareresearch.co.nz

Mahuru Wilcox

wilcoxm@landcareresearch.co.nz

Lara Taylor

taylorl@landcareresearch.co.nz

Jonno Rau

rauj@landcareresearch.co.nz

Puke Timoti

timotip@landcareresearch.co.nz

1 Manaaki Whenua Landcare Research, Gate 10, Silverdale Rd., Hamilton, New Zealand
When European settlers colonised Aotearoa New Zealand in the early nineteenth century, they brought with them an imperial mindset and values that were at odds with those of the Indigenous Māori. Māori relied solely on their ability to sustainably manage the resources within their area to survive (Mihinui 2002). Māori were subsequently marginalised and displaced from their homelands, and their tribal lands were cleared to create grounds for pastoral farming, horticulture, towns, and infrastructure to benefit the colonisers (Moewaka-Barnes and McCreanor 2019). Driven by a capitalist ideology, their goal was to convert as much land as possible into economically productive landscapes. There was rapid clearing of forests, planting of exotic pasture grass species, drainage of wetlands (Moewaka Barnes and McCreanor 2019), and diverse cultural landscapes were transformed into relatively homogenous production units. This resulted in physical, spiritual, mental, and physiological disconnection of Māori from their whenua (lands).

Fast forward to the environmentally disastrous impacts of neoliberalism that we see today. In Aotearoa, our freshwater 
rivers, streams, lakes, and wetlands are poor and getting worse in most parts of the country (Ministry for the Environment \& Statistics NZ 2020). Our economic growth is fast approaching environmental limits (OECD 2017). Almost 4000 of our indigenous plant and animal species are currently threatened with or at risk of extinction, and our biodiversity has declined significantly (Ministry for the Environment \& Statistics NZ 2019). Increasingly stringent regulations are being rolled out by policy makers to protect natural systems, but these continue to be framed by Eurocentric measures and concepts. If we are to achieve our vision to improve the health of te taiao (the environment) and of people, we need to change the way that people interact with their environment from a position of extractive resource use, to one of reciprocal exchange. Te Ao Māori (the Māori worldview) thinking offers us a pathway forward to achieving sustainable livelihoods that also enables the natural world to prosper.

Fundamental to Te Ao Māori worldview are the core values that Māori have developed over centuries of living in close connection with te taiao (Harmsworth and Awatere 2013). For example, the value of whanaungatanga (kinship) describes the interconnected relationships between people, natural resources, place, and bodies of knowledge. These kinship connections are premised through whakapapa (genealogy), which conjures ideas of layering that builds upon the past towards the present and into the future, both in terms of reciting genealogy, and as a metaphor for the creation and evolution of all living creatures (Harmsworth and Awatere, 2013). Within this context, Māori ways of knowing consider natural resources to be taonga, (treasures or gifts) that have been handed down to us through whakapapa from the primal parents, Ranginui (the sky father) and Papatūānuku (the earth mother), and our tūpuna (ancestors). The value of kaitiakitanga (guardianship) represents a Māori paradigm of resource management that gives primacy to the wellbeing of human communities and natural ecosystems, and includes spiritual and metaphysical elements that are integral to Māori culture. Māori people are obligated to practice kaitiakitanga because of their kinship relationships, through whakapapa and whanaungatanga that they experience with their environment (Waitangi Tribunal 2011).

These values act as guiding principles for considering and developing ever-evolving indigenous knowledge, or mātauranga Māori. Mātauranga Māori refers to Māori knowledge, worldviews, philosophy, values, ethics, and quantitative observations (Harmsworth and Awatere 2013; Hikuroa 2017). Other terminology associated with mātauranga include māramatanga (to understand), mōhiotanga (to know) and akona (to learn) (Muru-Lanning 2012). Mead (2012) defines mātauranga Māori as dynamic and evolving, whilst maintaining the values and ethics that underpin Te Ao Māori.
Mātauranga Māori is <thus> made up of a core of traditional knowledge plus the values and ethics that go with it and new knowledge, some of which we have added as a result of our discoveries and research, and some we have borrowed outright from western knowledge and from our experiences of living with exponents of other belief systems and other knowledge systems. We are now reshaping, rebuilding, reinterpreting and reincorporating elements of mātauranga Māori to make it fit the world that we live in today (Mead 2012).

As we delve into what mātauranga Māori is in postcolonial Aotearoa, we are confronted with issues around loss of knowledge and how we communicate mātauranga Māori within a resource management framework poorly aligned with a Te Ao Māori approach (Chambers 2009; Mead 2012, 2003; Muru-Lanning 2012).

A combination of New Zealand's Eurocentric policy and legislative frameworks, together with social inequality, have led to the disempowerment and marginalisation of Māori values, issues and knowledge (Joseph 2008; Tipa and Welch 2006; Mead 2012; Selby et al. 2010). This is at odds with The Treaty of Waitangi 1840 (the Treaty), New Zealand's founding document, which sets out key principles to guide governance and partnership between Māori and the Crown (the NZ government) (Cabinet Office 2019). The Treaty principles, according to Te Puni Kōkiri, the Ministry of Māori Development (2001), include: partnership (between the Crown and Māori), active protection (the Crown's obligation to protect Māori interests), and redress (past wrong doings have the right of redress). These principles reflect the intention and spirit of the Treaty, and their interpretation is constantly evolving as the Treaty is applied to contemporary issues and situations (Te Puni Kōkiri, 2001).

The development of enduring and substantive partnerships between Māori and scientists, planners, and decision makers, is crucial for developing natural resource management plans and practices that are generative and equitable, and that will ensure sustainable livelihoods for tangata whenua (the Indigenous people of the land) (Edwards et al. 2018).

In this paper we utilise He Waka Taurua, a framework for collaborative partnership based on the dual elevation of both Te Ao Māori and western science knowledge systems (Maxwell et al. 2020). We then describe a case study to demonstrate how this partnership framework has been operationalised across a Māori agribusiness in the East Coast of NZ to co-produce outcomes based on science and indigenous knowledge. Issues around the operationalising of mātauranga Māori within natural resource management are discussed further. 


\section{He Waka Taurua—the double-hulled canoe}

He Waka Taurua, the double-hulled canoe, is a metaphorical framework that elevates indigenous worldviews, values, and practices, alongside western science, and knowledge (Maxwell et al. 2020). The framework can be used to guide the development of collaborative partnerships useful in co-governance, co-management, or cross-cultural research.

New Zealand is increasingly improving its obligation to Māori by incorporating Kaupapa Māori principles and ideologies into decision-making frameworks and approaches for resource management (Maxwell et al. 2020). For example, Edwards et al. (2018) developed a conceptual framework that combines integrated adaptive governance, action research and Kaupapa Māori principles to better manage complex environmental decision-making. At the same time, Edwards et al. (2019) identified the need for a bottom-up, community driven approach to resource management decision making based on the sustainable livelihoods approach. Māori are also developing decisionmaking frameworks from a Māori ideology. The He Waka Taurua framework for example, conceptualised a decision-making framework through a Te Ao Māori lens, with the symbolic waka intended to serve as a 'Maōri cultural memory retention device' (Maxwell et al. 2020). He Waka
Taurua explicitly identifies a Te Ao Maōri worldview and associated values as a distinct and complete knowledge system, separate from a western science worldview. This is represented by the two hulls, Waka Māori and Waka Tauiwi, and the hoe (paddles), which represent the tools, actions and approaches relevant to each worldview. These worldviews are kept separate from each other, whilst the papanoho (deck) between the canoes represents a shared or 'negotiated space', where engagement and innovation can occur (Maxwell et al. 2020). This depiction can also help to clarify how well Māori knowledge, principles, and practices, are upheld, and applied, relative to those of western science or the values of broader NZ society (Maxwell et al. 2020).

Collaborative partnerships between Indigenous groups and western scientists, policy makers or decision makers, will be most successful when they are based on mutual acknowledgement and respect for different worldview ideologies and knowledge systems, whilst also providing a mutual space for engagement, shared aspirations, and innovation (Fig. 1).

He Waka Taurua provides a useful starting point for Indigenous and non-Indigenous people to engage in a partnership to enable more sustainable management, and therefore better outcomes for the environment and all its people.We utilised the He Waka Taurua framework to guide

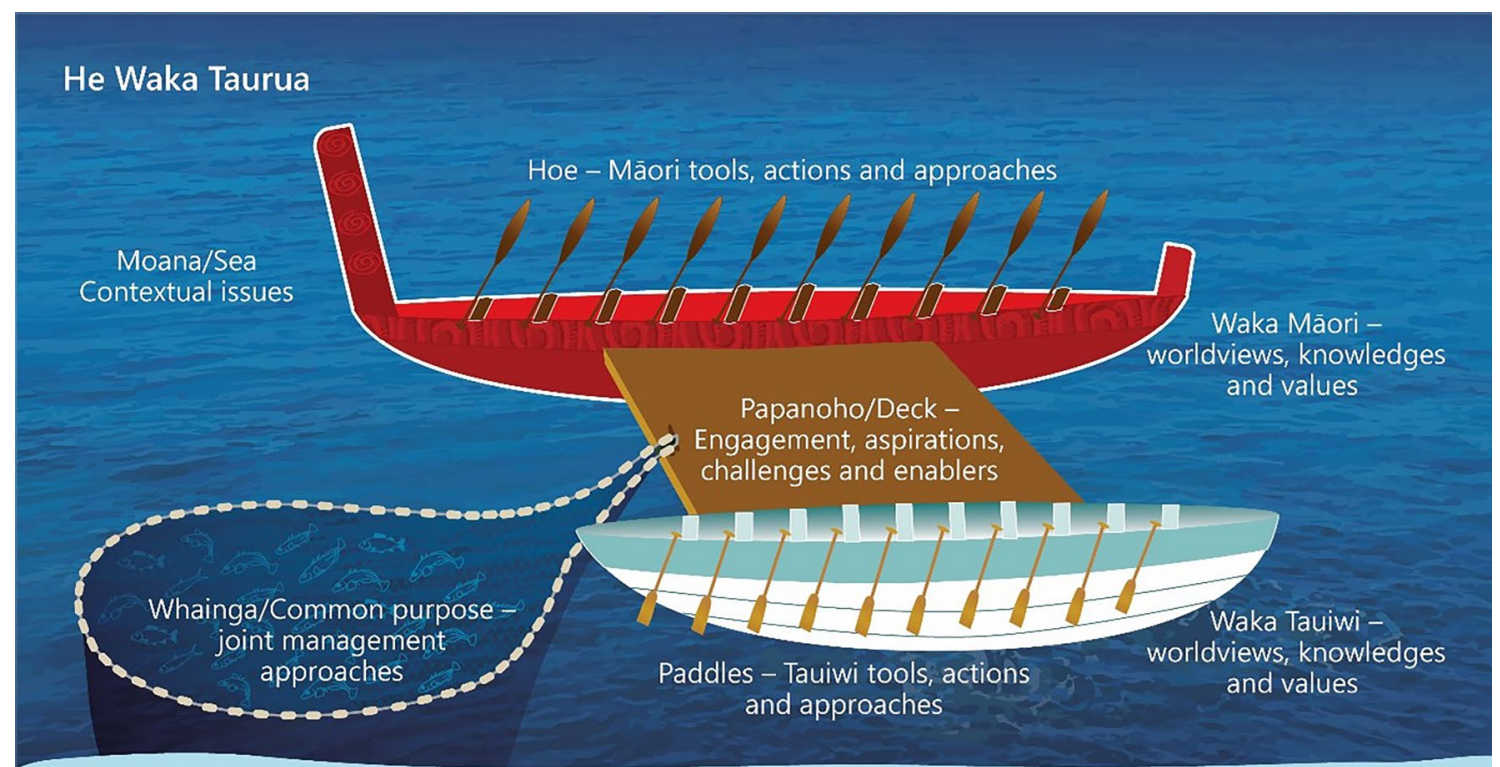

Kupenga/Net

Fig. 1 He Waka Taurua framework for recognising multiple worldviews and achieving co-governance, co-management, or cross-cultural research (Maxwell et al. 2020) 
a partnership approach between researchers and Māori trustees of a Māori agribusiness case study (Whakatāwai Station) for the co-production of knowledge and informed decision-making. The case study is presented next.

\section{Case study-Whakatāwai Station}

In this section we present the Whakatāwai Station case-study to demonstrate how He Waka Taurua was operationalised for the co-development of knowledge between a Maōri agribusiness and Māori researchers, and how this knowledge was used to transform a pastoral grazing unit into a system that better aligned with Māori values and aspirations. We then discuss more widely how co-development of knowledge as demonstrated by this case-study can lead to more informed decision-making in natural resource management across Aotearoa.

Whakatāwai Station is located in the Waiapu Valley, East Coast, New Zealand (Fig. 2). Prior to European colonisation, the Waiapu Valley was a thriving community with mosaics of different crops under cultivation, including kumara (sweet potato, Ipomoea batatas) and taro (Colocasia esculenta) (Beckwith 2007), and pockets of activity were sited according to the most favourable soil and landform characteristics. By $1840,80-90 \%$ of the catchment was still under natural forest (Harmsworth et al. 2002), with high biodiversity of plant and animal species, and an intimate connection of people to their land and the natural world. At this time, Te Ao Māori was the only knowledge system, and all decisions were made within the context of Te Ao Māori thinking and being.

In the late 1800's, large areas of land were cleared for pastoral farming, promoted by government incentives such as tax breaks for land development and discounted loans (Rhodes 2001). This continued in the late 1970's, with farmers being encouraged to convert unimproved or reverted hill-country land into grazing land through government provision of a Land Encouragement Loan (Ministry of Agriculture and Fisheries 1981). Thus, for Māori communities of the Waiapu Valley who owned large land parcels, conversion of the land into pastoral farms was actively encouraged. Te Ao Māori thinking and being had been marginalised in favour of the Eurocentric worldview. Capitalist incentives drove expansion of primary production where there was poor matching of land type with land management practices, and subsequent negative impacts in surrounding natural systems and receiving environments. For the Māori communities in the Waiapu Valley, destabilisation of soils through deforestation led to increased erosion and sedimentation of the waterways (Marden 2012), and the associated loss of biodiversity of plant and animal species and creation of an exotic grassland has had a profound impact on cultural values and their enactment. This was the experience for Whakatāwai Station.

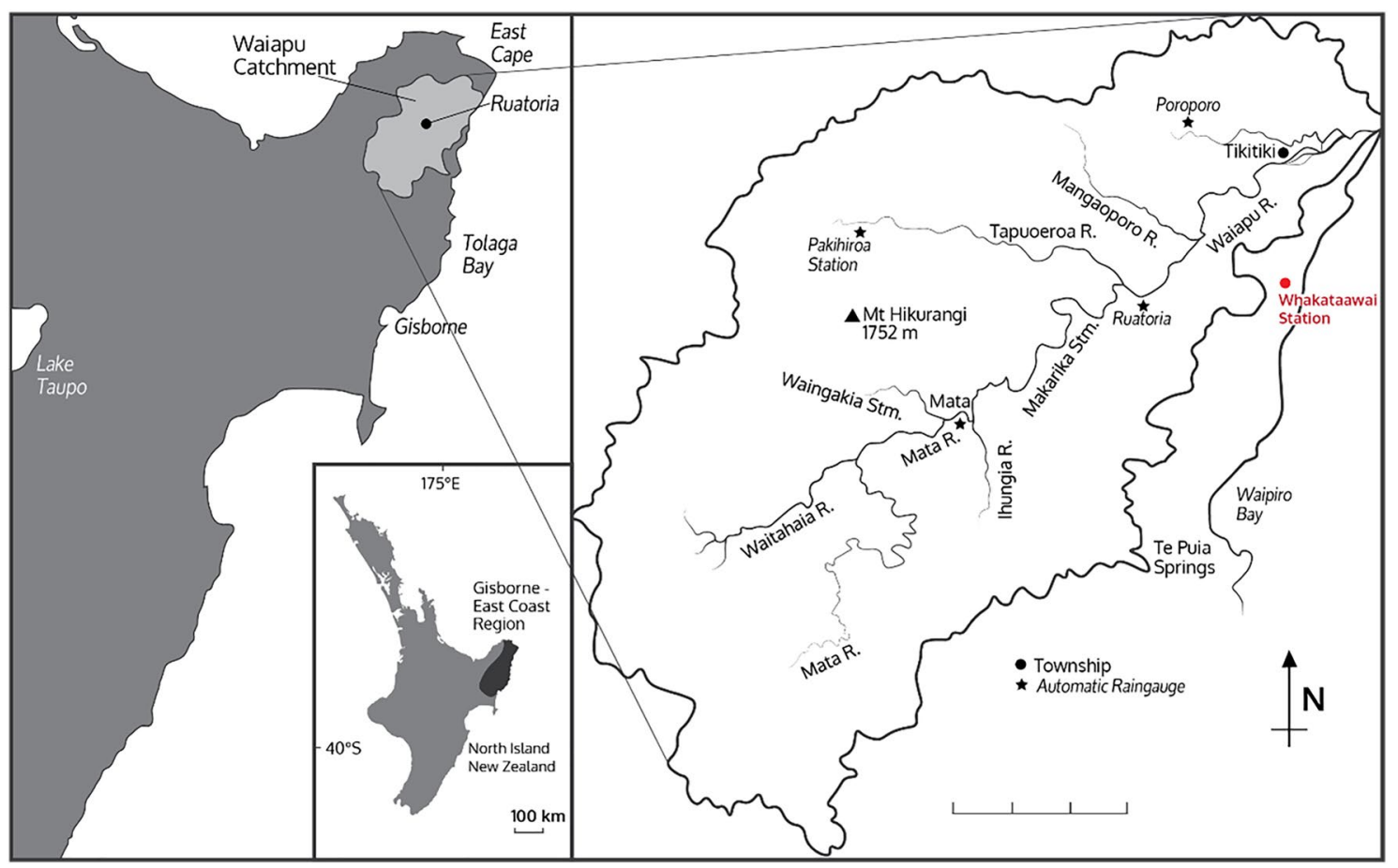

Fig. 2 Location of the Waiapu Catchment, East Coast, North Island, New Zealand. (Reproduced from Parkner et al. 2007) 
The Waiapu catchment is characterised by steep slopes, and even under indigenous forest the land was erosion prone due to a combination of factors including tectonic influences (e.g., earthquakes, uplift rates), geological influences (rock type, degree of faulting and crushing) and having a dynamic climate influenced by tropical cyclones (Marden 2012). The effects of deforestation on erosion in this catchment (Hill 1895; Henderson and Ongley 1920) and the link between increased sediment loading in rivers and channel aggradation and increased flooding events (Kennedy 1912; LaingMeason 1914), were first observed between 1880 and 1920 . The increase in clearance of vegetation from the steepest slopes over the last $40-50$ years has exacerbated the severity of erosion in the catchment.

Whakatāwai Station is currently leased for pastoral grazing, a land use deemed unsustainable by the committee of management due to it having a high proportion of erodible marginal land that is predicted to be at further risk of erosion due to climate change. The current land use activity does not deliver on the aspirations of the shareholders and governance because the current environmental state is poor, with low biodiversity of plants and animals, and disconnection of the shareholders from their ancestral land. This current state does not align with the central concept of connectedness, or whanaungatanga that underpins Māori ways of knowing and being. Understanding the story of how the Whakatāwai Station shareholders became disconnected from their whenua, with accompanying loss of mātauranga Māori, customary protocols, and language, is key to revitalising the health of the land and her people.

Whakatāwai Station's journey and current predicament are testament to the negative consequences that arise from marginalising Māori perspectives and management approaches in ecosystem management in favour of Eurocentric ones. Clearly inequalities in knowledge sharing do not lead to best outcomes. A shared engagement space that can connect the different knowledge systems such as provided by the He Waka Taurua framework offers a transformational way forward. Thus, we utilised the He Waka Taurua Framework to guide the partnership approach between the researchers and Whakatāwai Station shareholders to co-produce decision-making outcomes, based on both science and indigenous knowledge. This was done by taking a true codevelopment approach and operating at the research interface where indigenous and non-indigenous knowledge systems share knowledge and perspectives. Herein, we describe a process that utilised a Kaupapa Māori approach to draw on relevant and meaningful knowledge, grounded in local experiences, in parallel with quantitative data gathering.

To understand why the current land use does not deliver on their aspirations, it is necessary to understand what these are. We engaged in a series of interactive workshops with the shareholders to understand their aspirations, perspectives, and priorities for their whenua in terms of potential land use opportunities, and codeveloped a model for utilising cultural values to inform their land management decisions. The project was initiated by a first meeting between the project team leads and the committee of management, to understand their aspirations for the Waiapu catchment, their farm, and the case study farm block. The project team leads comprised a diverse set of skills, being themselves Māori, and having subject expertise in ecology, governance, economics and Kaupapa Māori research disciplines.

Thinking about the He Waka Taurua framework, the committee of management were in one waka with their local place-based knowledge, and the researchers in the other, bringing their Western knowledge system to the platform. It is acknowledged that our researchers grounding in Kaupapa Māori research conveyed an advantage to the co-production process because they had a heightened ability to facilitate the integration of the two knowledge systems. However, the essential point here is the bringing together of the indigenous and non-indigenous ways of knowing in a common platform so that genuine co-development can occur, and each knowledge system is regarded as equally valid.

Kaupapa Māori is a Māori-led research methodology that is based on Māori concepts, values, and principles, see for example (Barnes 2009; Hudson and Russell 2009; Irwin 1994; Kerr 2012; Morgan et al. 2021; Smith 2021). As a starting point, we presented the Māori values framework developed by Awatere et al. (2014) to the committee of management that is based on three core values: Kaitiakitanga (sustainable management), Manaakitanga (reciprocity), and Whakatipu Rawa (growing the asset base). Thinking about how we implemented the He Waka Taurua framework in our practice, project researchers brought together their western scientific technical expertise with the place-based knowledge contributed by the committee of management by working through the Māori values framework (Awatere et al 2014) together. This was an effective way to support our research partners in organising their knowledge through utilising a relevant tool that had been designed according to their worldview (te ao Māori). The qualitative technique works by enabling users to ascribe qualitative rankings such as low, medium, and high to mauri-based criteria. In this context, mauri is described as the perceived life force of something (e.g., indigenous plants). It builds on methods to determine mauri (Tipa and Teirney (2003), Morgan (2006), Harmsworth \& Tipa (2009). The Māori values framework (Awatere et al. 2014) has been successfully applied in a number of contexts, for example in the assessment of alternative afforestation opportunities for forestry and horticulture in the context of climate change for the Waiapu catchment (Awatere et al 2018); and land resource assessment undertaken by the Arai-Matawai Incorporation (Awatere and Harcourt 2020). The Whakatāwai Station case study enabled us to 
bring the thinking from our experience utilising the Māori values framework, alongside Western knowledge according to the He Waka Taurua framework.

With reference to He Waka Taurua, the Māori values framework form the paddles (hoe) for our Māori partners, being the approach that was taken to provide knowledge to the shared platform. Thus, we adopted the qualitative technique used by Awatere et al. (2014) to identify attributes relevant for assessing alternative land use opportunities. Table 1 describes the qualitative rankings (pōhara/poor, ăhua pai/okay, pai/good and pai rawa/excellent), framed from a Māori perspective, that can be utilised for assessing alternative land uses based on expert judgement. These qualitative rankings were assigned to attributes for the three core Māori values (Kaitiakitanga, Manaakitanga and Whakatipu Rawa, Table 2).

As described in Awatere and Harcourt (2020), the impact of an activity on Māori values is a key decision factor for assessing land use options. These values were supported by the committee of management for Whakatāwai Station, who identified 'landuse impacts on kaitiakitanga' as their key priority for decision making. They also identified erosion mitigation as a critical factor for any future land use opportunities, and they recognised that afforestation would provide better erosion control than pastoral grazing (the current land use). Indeed, the very act of restoring soil integrity by planting is a demonstration of enacting kaitiakitanga.

We walked the whenua with the trustees and shared knowledge about biophysical observations (past and present), cultural significance and sites of special meaning, and we discussed potential economic returns from undertaking different activities according to biophysical and cultural feasibility. Understanding place-based knowledge and mātauranga about what had grown historically on a site and microclimate considerations will provide robust guidance for understanding what is feasible. From a Māori perspective, a changing climate has the potential to impact on the balancing of the four domains: cultural, social, environmental, and economic, and therefore decisions about the whenua need to incorporate projected scenarios. Māori look to the past as a guide for the present and future. To ensure that we included as many shareholder voices as possible, we held a teleconference call and engaged governance and shareholders to mark significant sites on a shared map of the case study site. Kaumātua (elders) shared mātauranga about the genesis of the site name, location of dwellings, wāhi tapu (sacred sites) and wāhi taonga (sites of significance), important rongoā (indigenous plants used in natural medicine and wellness) and taonga species (native plants and animals of cultural significance), and activities that had been undertaken in relation to the land block. We learnt that the study site has special cultural significance, containing an urupā (cemetery), a church, two pā sites (fortified landforms), and was the site of an old homestead, but that few shareholders are connected to this knowledge. The trustees identified Tî kōuka (NZ Cabbage Tree, Cordyline australis) as a taonga species on their whenua.

Weaving together our knowledges, both mātauranga Māori and western, according to the He Waka Taurua framework, enabled us to compile a high-level list of alternative land uses. The novelty of our framework lies in conceptualising the landscape from a Māori world view, and in

Table 1 Variables utilised in Kaupapa Māori assessment

\begin{tabular}{lll}
\hline Pai rawa - Excellent & $\checkmark \checkmark \checkmark \checkmark$ & All \\
Pai-Good & $\checkmark \checkmark \checkmark$ & Most \\
Āhua pai-Okay & $\checkmark \checkmark$ & Some \\
Pōhara-Poor & $\checkmark$ & Few \\
Aue-Low & & None \\
\hline
\end{tabular}

Table 2 Value domains and assessment attributes for decision-support tool

\begin{tabular}{lll}
\hline Core values & Parameters & Data \\
\hline Kaitiakitanga & $\begin{array}{l}\text { Perceived impact on the mauri of culturally significant sites, food-gather- } \\
\text { ing areas, culturally significant plants, culturally significant waterways } \\
\text { Manaakitanga } \\
\begin{array}{l}\text { Perceived impact on the potential to stimulate education opportunities, } \\
\text { community connectedness, cultural pride, commercial relationships with } \\
\text { other iwi/hapu/wider community }\end{array}\end{array}$ & Ranking by trustees and landowners/beneficiaries \\
Whakatipu Rawa & $\begin{array}{l}\text { Perceived impact on the potential to provide equitable shared benefits } \\
\text { across generations, retention of fixed assets, full-time equivalent } \\
\text { employment }\end{array}$ & Ranking by trustees and landowners/beneficiaries \\
\hline
\end{tabular}


utilising the technical underpinnings of associations between plants and soil-landforms on the whenua (land) to develop a high-level list of potential planting options to be further refined by a prioritisation process as led by a cultural values assessment. Thus, our framework can work alongside existing technical tools and repositories. With reference to the paddles (hoe) for the Western knowledge, we utilised standard scientific techniques including soil assessment (e.g., digging soil profile pits to observe key attributes), topographical mapping and data overlays, along with botanical site mapping, and climate maps. Bringing together place-based knowledge with the technical data in the shared engagement space made it possible to generate the high-level list of alternative land uses according to what was feasible based on biophysical and cultural as well as social and economic considerations. This high-level list included afforestation for various applications including mānuka monoculture (Leptospermum scoparium), a tree that generates high value honey and oil, mixed mānuka and rongoā farming, and rongoā farming alone. The list was further refined by the committee of management, enabling them to rank the potential of each to deliver on their aspirations. In addition to the status quo land use (pastoral grazing), alternative potential land uses were ranked according to a Kaupapa Māori assessment of their relative contribution to three criteria: kaitiakitanga, manaakitanga, and whakatipu rawa.

Aggregated scores were obtained for each of the alternative land use scenarios and compared. With reference to kaitiakitanga indicators (Table 2), while pastoral grazing was assessed as having a degrading mauri (reduced environmental vitality) because it exacerbates erosion and diminishes biodiversity, and it was thus deemed aue or low (contributing nothing to kaitiakitanga values, Table 1), all forms of afforestation were assessed as increasing mauri. However, the highest weightings for kaitiakitanga were given for mānuka and rongoā farming (pai rawa - excellent), because the trustees recognised that having a diverse mix of plant species would generate the highest biodiversity. They also recognised that the mature ngāhere (forest) option would likely promote healthy mahinga kai (cultivated food-gathering sites) and mahinga rongoā (traditional medicine gathering sites) sites through habitat stabilisation and enhancement. Afforestation scenarios were also understood to generate better connectivity with beneficiaries and the community associated with the farm, and therefore improved manaakitanga. By celebrating the taonga species and incorporating information that had been provided by the participants about mâtauranga and where they would like plants to be sited, and species combinations, the participants were further connected to their whenua.

With respect to kaitiakitanga aspirations, rongoā plant species grow where they are required and are a key part of healing the landscape and people, making this activity well aligned. This thinking is core to Māori concepts of wellbeing as encapsulated in the whakatauki (proverb):

Ka ora te whenua, ka ora te tangata.

If you heal the land, you heal the people.

Kingi Tāwhiao Te Wherowhero.

This opportunity enables links to restoration of the wetlands and riparian zones, and increased biodiversity of flora and fauna. Sustainable harvest of the plant species by removing limited amounts of foliage or bark from the tree without harming the plant's ongoing growth potential or disrupting the root system is consistent with kaitiakitanga values. It may also enable restoration of the ancestral ecosystem and is consistent with Māori concepts of intergenerational timeframes with a long-term view.

An industry based on sustainable extractives has the potential to support community involvement and to utilise labour across the calendar year. The potential to increase labour and revenue generated by honey and oil production from mānuka in addition to native plantings meant that the mixed afforestation scenario was perceived to be the most desirable land use option. It would also build capability within the community to develop and utilise rongoā. By enabling the trustees to evaluate the alternative land uses against their core values, they were able to conclude that the loss of revenue from retiring some of the land blocks for planting, and the costs associated with this (fencing, weed and pest control and planting), was offset by the long-term benefits of environmental mitigation.

In the mid-long term, the benefits of knowledge sharing as facilitated by the He Waka Taurua framework will build capacity and capability for all research partners involved. For the shareholders of Whakatāwai Station, the learnings from the project itself will go beyond testing the He Waka Taurua framework alone. They are likely to include capability gains in land use decision-making, and reconnection with traditional plant use and associated knowledge. The afforestation opportunities identified by the process have the potential to support high levels of community involvement (e.g., plant propagation, harvesting). Re-establishing the connections between Whakatāwai Station shareholders and their whenua (land), ancestral knowledge (mātauranga), customary protocols (tikanga) and language (te reo), is therefore key to revitalising the health of the land and her people. Taking a partnership approach to farm planning, incorporating the technical wisdom of conventional farm advisors and scientific testing methods alongside a Kaupapa Māori assessment, offers exciting possibilities for sustainable agribusiness through creating mosaics of land uses that are more resilient and prosperous. 


\section{Discussion}

Recent changes to Aotearoa's environmental policy and legislation recognises the need for more holistic, integrated, and bicultural provisions to address the multitude of complex environmental governance and management issues. Here, we suggest that collaborative partnership is required and must be based on the dual elevation of both Te Ao Māori and Western knowledge systems. In Aotearoa, we are starting to see promising signals for partnership. One of the most ground-breaking developments has been the passing of the Te Urewera Act (2014) and the Te Awa Tupua (Whanganui River) Act (2017), which recognise the Te Urewera Forest and the Whanganui River as having legal personhood, with all the rights of a person. In alignment with this recent Treaty settlement legislation that recognises the inherent rights and authority of nature itself, the National Policy Statement for Freshwater Management (2020), acknowledges Māori Indigenous principles and values, and gives prominence to Te Mana o te Wai (TMOTW) (the authority of water itself), which emerges from a Te Ao Māori perspective. While these are promising signals for partnership, it is important to recognise that implementation of Māori informed legislation provisions like Te Mana o te Wai is directed by, and at the discretion of, regional councils with no clear mandate or role for Māori in governance and decision-making. Despite the bicultural rhetoric, there are a lack of methods to support implementation of Te Ao Māori informed provisions (Matunga 2000). These comments can be extended to include Māori involvement in natural resource management more broadly (including management of farm paddocks, and plant and animal species), more holistic, integrated, and bicultural provisions to address the multitude of complex environmental governance and management issues.

However, there are examples of civil society enabling Māori to have an active voice in natural resource management, such as Te Ture Whaimana o Te Awa o Waikato-the vision and strategy for the Waikato River (Waikato-Tainui Te Kauhanganui Inc 2013). Te Ture Whaimana is a direction-setting document for the restoration and protection of the Waikato River and its catchment (including wetlands), guided by Kīngi Tāwhiao's (the second Māori King) maimai aroha (lament):"Tōku awa koiora me ōna pikonga he kura tangihia o mātāmurithe river of life, each curve more beautiful than the last". Te Ture Whaimana sets out an integrated and collaborative approach between Waikato River iwi (tribes), local authorities, and stakeholders, to restore and protect the health and wellbeing of the Waikato River for future generations (Waikato-Tainui Te Kauhanganui Inc 2013). Te
Ture Whaimana also actively promotes the utility of Iwi Environmental Management Plans and other formally recognised plans and agreements into mainstream planning processes.

Recent and emerging mainstream legislation and policy are responding to Māori rights and interests with respect to the natural environment. The Resource Management Act 1991 (RMA), and National Policy Statements (of which we have discussed the NPS-FM, pertaining to freshwater management), and the Zero Carbon Act are the most significant. These Acts are operationalised via regulations for water quality at regional and sub-regional levels, and through national carbon regulations. For example, the New Zealand Government recognises that production of net greenhouse gas emissions (excluding biogenic methane) needs to be reduced, and under the Climate Change Response-Zero Carbon Amendment Act 2019, the target is to achieve zero emissions by 2050 . To achieve this target, the government has created incentives to help farmers meet new environmental regulations. A key example is Te Uru Rākau-One Billion Trees (Ministry for Primary Industries 2021), an afforestation scheme that aims to double the current planting rate to reach one billion trees by 2028 , with a focus on the right tree, in the right place, for the right purpose. There is $\$ 240$ million available in funding for tree planting by landowners, and two thirds of the funding is earmarked for indigenous species. The other incentive is the Freshwater Improvement Fund (Ministry for the Environment (2021a), where funding is available as part of the $\$ 1.3$ billion Jobs for Nature environmental funding programme, to: reduce sediment eroding from the land; wetland construction and restoration; stream reinstatements; estuary protection and restoration; restoration of fish passage; job creation and building capacity and capability in freshwater management and restoration. Māori ways of thinking about care and protection of the environment align well with these new signals from government and offer useful frameworks to implement sustainable ways of being. Appointment of the Climate Change Commission, a new Crown entity charged with providing independent evidence-based advice to government, is another hopeful demonstration of the NZ Government's willingness to start thinking about new ways of meeting our obligations to the environment. However, it is noted that just one of the seven commissioners is Māori.

The Emissions Trading Scheme (Ministry for the Environment 2021b) is another example of a government legislation to encourage reduction of greenhouse gas emissions. It creates a financial incentive for businesses to reduce emissions and landowners to derive an income by planting forests that absorb carbon dioxide. Each tonne of tree growth is assumed to represent a tonne of carbon sequestered (equivalent to one carbon credit). This is essentially an accounting exercise, and the legislation and its regulations 
are volatile, but there is ongoing government commitment to this system. The NZ Government has recently announced that they will be lifting the carbon credit price for indigenous trees to encourage their planting. This is exciting news for Māori because it aligns with their aspirations to reintroduce taonga species into the landscape, but the ability for Māori to contribute to the legislation and its regulations remains limited. Regulations set by government around discharges (e.g., agri-chemicals, nutrients, sediment, greenhouse gases) may restrict or promote land use activities, and do not consider Māori values and attributes.

There are several other proposed regulations in train, such as the National Policy Statement for Highly Productive Land (NPS-HPL). The intent of this legislation is to prevent the loss of more of our productive land and promote its sustainable management and improve the way it is managed under the Resource Management Act 1991. Also, the Draft National Policy Statement for Indigenous Biodiversity is currently being developed (Ministry for the Environment 2021c). This sets out the objectives and policies to identify, protect, manage, and restore indigenous biodiversity under the RMA.

Notwithstanding the many policy and legislative initiatives that support Māori interests and aspirations, the importance of true partnership in management of natural resources is described in Taylor et al. (2020). It is argued that Māori should be able to utilise policy settings that are relevant to their own worldview, given that this is guaranteed under the Treaty of Waitangi. As a starting point it is argued that environmental resources are 'taonga' (treasures), and that a tikanga-based framework needs to be implemented for appropriate management of natural resources. Taylor et al. (2020) suggested that this could, at a minimum, be created within the current policy settings, albeit with changes that elevate protection of and provision for cultural values alongside environmental values. This type of transformation in a partnership approach to resource management is critical to achieving sustainable outcomes. More than just achieving critical buy-in from a disenfranchised sector of the community, implementation of Te Ao Māori ways of thinking and doing will stimulate more caring attitudes towards the environment. The value of changing attitudes toward resource management from one of exploitative, human-centred thinking, to a more reciprocal relationship is not new (see Marsden 1988 and Harmsworth and Awatere 2013). A fundamental shift is required that recognises and is attentive to the inherent reciprocity in the relationship between the health of the environment and the health of people, and this also requires healthy culture and economy (Awatere et al. 2017).

Yet it needs to be acknowledged that there are difficulties with successfully communicating mātauranga Māori within a science dominated arena to achieve useful outcomes. One of these is describing concepts and values of Te Ao Māori using scientific language and scientific frameworks (Allen et al. 2011; Harmsworth 2001; Joseph 2008; Kinloch and Metge 2014; Muru-Lanning 2012; Townsend et al. 2004). Te reo Māori (Māori language) has been shaped by Māori communities to express Māori culture and there are risks of this being 'lost in translation' (Joseph 2008). Another issue with cross-cultural research, is the risk of assimilating world views (Smith 2013).

The challenges for co-development of knowledge regarding agribusiness planning are consistent with those outlined above. If partners do not share the same worldviews, then conflicts may occur. We propose that involving Māori in setting legislation is critical to ensure that there is alignment of values between Māori landowners and regulators. However, we acknowledge that logistically, there may be a lack of capacity within Māori organisations, limiting their ability to participate in planning, and that capacity building remains a critical need for many (Awatere et al. 2017; Te Kawa Mataaho Public Service Commission 2021).

Thinking about how our case study provides learning about operationalising mātauranga Māori within natural resource management, we conclude that utilising the He Waka Taurua framework enables equitable sharing of knowledge from the two worldviews. Our case study demonstrates that different knowledges and perspectives each retain their own validity according to a parallel workstreams approach. Brought together in the shared engagement space, the cultural values assessment (qualitative) and biophysical indicators (quantitative) work together to ensure that the information generated is robust and fit for purpose. The cultural values assessment would need to be constrained by what the biophysical indicators say is likely to grow in a particular location (e.g., if the aspiration is to re-establish fragile swamp plants, they will not be planted in droughtprone hill slopes).

We also suggest that holistic thinking is crucial for restoring ecosystems that are complex and interconnected. Partnership requires collaboration and coordination, which are complex processes, given the differing cultures and values, protocols and structures, and systems of a multitude of parties. The NZ Government has recently launched He Waka Eke Noa-Our Future In Our Hands, a partnership between the primary sector, government and iwi/Māori, to design a practical and cost-effective system for reducing greenhouse gas emissions by 2025 , and to build climate change resilience (Ministry for the Environment 2019). To achieve impact, there must be a common shared set of values and principles. He Waka Eke Noa clearly states that there must be genuine partnership between all parties, and that there will be an inclusive and participatory approach with codesign of key deliverables and milestones. So, we conclude by referring to the Treaty, and to the promise that our tūpuna 
(ancestors) were given, that Māori will finally be able to cogovern natural resources in our ancestral homeland.

\section{Conclusion}

We have identified the common challenges and opportunities of bringing together Māori worldviews, values and practices, alongside western science and knowledge. Key challenges include that legislation and policy are framed by Eurocentric measures and concepts. There is no clear mandate for Māori in governance and decision-making in some of the key legislation coming out of government, despite acknowledgement of Māori principles and values. Further, there are a lack of pathways to enable Māori knowledge and processes, and methods to support implementation of principles within legislation. Co-production of knowledge theory is hampered by the inherent difficulties of communicating mātauranga Māori within a science dominated arena to achieve useful outcomes. The risk of assimilating world views remains a challenge. The lack of capacity within Māori organisations limits their ability to participate in all planning opportunities, as is desired. Yet there are many opportunities, including increased understanding and positive transitional change from the government, such as Treaty-compliant water management and a commitment to managing climate change. Te Ao Māori thinking aligns with some of these new signals coming from the government, and societal expectations about the impacts of primary production on cultural, social, and environmental wellbeing. Recent changes to Aotearoa's environmental policy and legislation recognises the need for more holistic thinking, including the incorporation of Te Ao Māori thinking. Lastly, there are several existing models and frameworks that demonstrate how collaborative partnerships can be operationalised.

\section{Glossary}

$\begin{array}{ll}\begin{array}{ll}\text { Akona } \\ \text { Hapū }\end{array} & \begin{array}{l}\text { To learn } \\ \text { Sub-tribe(s) that share a common } \\ \text { ancestor }\end{array} \\ \text { Iwi } & \begin{array}{l}\text { Tribe)s); tribal kin group; nation } \\ \text { Guardianship; sustainable management } \\ \text { Kaitiakitanga }\end{array} \\ \text { Kaumātua } & \text { Elder(s) } \\ \text { Kaupapa Māori } & \begin{array}{l}\text { Māori approach to research by Māori } \\ \text { for Māori }\end{array} \\ \text { Mahinga kai } & \text { Cultivated food gathering sites } \\ \text { Mahinga rongoā } & \text { Traditional medicine gathering sites } \\ \text { Manaakitanga } & \text { Respect; hospitality; mutual trust } \\ \text { Māramatanga } & \text { To understand } \\ \text { Mātauranga Māori } & \text { Māori knowledge } \\ \text { Mauri } & \text { Life essence, life force, energy, life } \\ & \text { principle }\end{array}$

Mōhiotanga

Ngahere

Pākehā

Pā site

Rongoā

Tangata whenua

Taonga species

Te Ao Māori

Te Mana o Te Wai

Te Taiao

Tūpuna

Wāhi taonga

Wāhi tapu

Wānanga

Whakapapa

Whanaungatanga

Whenua

To know

Forest

A person of European descent

Fortified landforms

Traditional medicine

Indigenous people of the land; first people of the land

Native plants and animals of cultural significance

Māori worldview

The vital importance of freshwater

The natural environment

Ancestors

Sites of signifcance

Sacred place

Workshops

Genealogy, ancestry, familial relationships

Relationship, kinship, sense of family connection

Acknowledgements Many thanks to the beneficiaries and committee of management for Whakatāwai Station. Thanks also to the reviewers and editors for their useful contributions. Ka nui te mihi ki a koutou.

Funding This research was funded by Strategic Science Investment Funding (SSIF) for Crown Research Institutes from the Ministry of Business, Innovation and Employment's (MBIE) Science and Innovation Group.

Open Access This article is licensed under a Creative Commons Attribution 4.0 International License, which permits use, sharing, adaptation, distribution and reproduction in any medium or format, as long as you give appropriate credit to the original author(s) and the source, provide a link to the Creative Commons licence, and indicate if changes were made. The images or other third party material in this article are included in the article's Creative Commons licence, unless indicated otherwise in a credit line to the material. If material is not included in the article's Creative Commons licence and your intended use is not permitted by statutory regulation or exceeds the permitted use, you will need to obtain permission directly from the copyright holder. To view a copy of this licence, visit http://creativecommons.org/licenses/by/4.0/.

\section{References}

Allen W, Fenemor A, Kilvington M, Harmsworth G, Young RG, Deans N, Horn C, Phillips C, Montes de Oca O, Ataria J, Smith R (2011) Building collaboration and learning in integrated catchment management: the importance of social process and multiple engagement approaches. NZ J Mar Freshwat Res 45(3):525-539

Awatere S, Harcourt N (2020) Whakarite whakaaro, whanake whenua: Kaupapa Māori decision-making frameworks for alternative land use assessments. In: Hill C (ed) Kia Whakanuia Te Whenua. Auckland: Landscape Foundation 
Awatere S, Tahi M, Daigneault A, Hainsworth SB, Fenemor A (2014) Whakatipu Rawa mā ngā Uri Whakatipu: Makirikiri aggregated trust case study. Manaaki Whenua - Landcare Research, Hamilton

Awatere S, Mika J, Hudson M, Pauling C, Lambert S, Reid J (2017) Whakatipu rawa ma ngā uri whakatipu: optimising the "Māori" in Māori economic development. AlterNative 13(2):80-88

Awatere S, Marden M, Warmenhoven T, Pohatu P, Daigneault A, Monge J, Dowling L, Harrison D, (2018) Climate Resilient Māori Land, contract report LC3133. Manaaki Whenua - Landcare Research, Hamilton

Beckwith J (2007) Tikapa: archaeological and ancestral landscape. MAI Review LW 1(2):6

Cabinet Office, Department of the Prime Minister and Cabinet (2019) CO (19) 5: Te Tiriti o Waitangi/Treaty of Waitangi Guidance https://dpmc.govt.nz/publications/co-19-5-te-tiriti-o-waitangitreaty-waitangi-guidance-html\#section-1. Accessed 6 Oct 2020

Climate Change Response-Zero Carbon Amendment Act (2019) https://www.legislation.govt.nz/act/public/2019/0061/latest/ LMS183736.html. Accessed 6 Oct 2020

Chambers C (2009) Mixing methodologies: the politics of research techniques. J R Soc N Z 39(4):197-199

Edwards E, Velarde S, Sharma-Wallace L, Barnard T, Pohatu P, Warmenhoven T, Porou T, Harrison D, Dunningham A (2018) Forest scholars empowering communities: A case study from the East Coast of New Zealand. Forest Policy Econ 91:46-53

Edwards E, Sharma-Wallace L, Barnard T, Velarde S, Warmenhoven T, Fitzgerald G, Harrison D, Garrett L, Porou T, Pohatu P (2019) Sustainable livelihoods approach to inform governmentlocal partnerships and decision-making in vulnerable environments. New Zealand Geogr 75:63-73

Harmsworth G (2001) A collaborative research model for working with iwi. Manaaki Whenua - Landcare Research, Palmerston North

Harmsworth GR, Awatere S (2013) Indigenous Māori knowledge and perspectives of ecosystems. Ecosystem services in New Zealand-conditions and trends. Manaaki Whenua Press, Lincoln, pp 274-286

Harmsworth G, Tipa G (2009) Māori environmental monitoring in New Zealand: progress, concepts, and future direction. Report for the ICM website

Harmsworth G, Warmenhoven T, Pohatu P, Page M (2002) Waiapu catchment technical report: Maori community goals for enhancing ecosystem health. Landcare Research report LC 0102/100 for Te Whare Wānanga o Ngāti Porou, Ruatoria (unpublished)

Henderson J, Ongley M (1920) The geology of the Gisborne and Whatatutu subdivisions, Raukumara division. In: Bulletin 21 (New Series). Geological Survey Branch, Department of Mines, Skinner WAG. Wellington: Government Printer

Hikuroa D (2017) Mātauranga Māori-the ūkaipō of knowledge in New Zealand. J R Soc N Z 47(1):5-10

Hill H (1895) Denudation as a factor of geological time. Transact Proc New Zealand Inst 28:666-680

Hudson ML, Russell K (2009) The treaty of Waitangi and research ethics in Aotearoa. J Bioeth Inq 6(1):61-68

Irwin K (1994) Maori research methods and practices. Sites 28:25-43

Joseph R (2008) Te hau mihi ata mātauranga Māori and sciencecross-cultural dialogue. University of Waikato, Hamilton

Kennedy CD (1912) Flood prevention report: Poverty Bay River District. Poverty Bay Herald 12 October, p. 5

Kerr S (2012) Kaupapa Māori theory-based evaluation. Eval J Australas 12:6-18

Kinloch P, Metge J (2014) Talking past each other: problems of crosscultural communication. Victoria University Press, Wellington

Laing-Meason G (1914) Prevention of floods: the Waipaoa River trouble. Poverty Bay River Board report on flood prevention. Gisborne Times, 17 July, p 11
Marden M (2012) Effectiveness of reforestation in erosion mitigation and implications for future sediment yields, East Coast catchments, New Zealand: a review. NZ Geogr 68(1):24-35

Marsden M (1988) The natural world and natural resources. Māori value systems and perspectives. Resource Management Law Reform Working paper 29. Part A. Ministry for the Environment, Wellington

Matunga H (2000) Decolonising planning: the treaty of Waitangi, the environment and a dual planning tradition. Environmental planning and management in New Zealand, 36-47

Maxwell K, Awatere S, Ratana K, Davies K, Taiapa C (2020) He waka eke noa/we are all in the same boat: a framework for co-governance from Aotearoa New Zealand. Mar Policy 121:104213

Mead HM (2012) Understanding mātauranga Māori. In: Black T, Bean D, Collings W, Nuku W, (eds). Conversations on mātauranga Māori. Wellington: NZQA

Mead HM (2003) Tikanga Māori: Living by Māori values. Huia Publishers, Wellington

Mihinui H (2002) Hutia te rito o te harakeke: a flaxroot understanding of resource management. In: Kawharu M (ed) Whenua: managing our resources. Reed publishing, Auckland, pp 21-34

Ministry of agriculture and fisheries (1981) Rural industries incentives 1981-1982. Media Services, Ministry of Agriculture and Fisheries, Wellington (NZ), p 42

Ministry for the Environment (2019) He Waka Eke Noa-our future in our hands. Primary sector climate change commitment. July 2019. https://hewakaekenoa.nz/wp-content/uploads/2020/12/primarysector-climate-change-commitment-july-2019.pdf

Ministry for the Environment \& Stats NZ (2019) New Zealand's environmental reporting series: Environment Aotearoa $2019 \mathrm{https}$ :// www.mfe.govt.nz/environment-aotearoa-2019. Accessed $23 \mathrm{Feb}$ 2021

Ministry for the Environment \& Stats NZ (2020) New Zealand's environmental reporting series: Our freshwater $2020 \mathrm{https}: / / \mathrm{www}$. stats.govt.nz/information-releases/new-zealands-environmen tal-reporting-series-our-fresh-water-2020. Accessed 23 Feb 2021

Ministry for the Environment (2021a) Freshwater Improvement Fund https://www.mfe.govt.nz/more/funding/freshwater-improvementfund. Accessed 17 Aug 2021

Ministry for the Environment (2021b) New Zealand Emissions Trading Scheme https://www.mfe.govt.nz/ets. Accessed 17 Aug 2021

Ministry for the Environment (2021c) Draft National Policy Statement for Indigenous Biodiversity https://www.mfe.govt.nz/publicatio ns/biodiversity/draft-national-policy-statement-indigenous-biodi versity. Accessed 17 Aug 2021

Ministry for Primary Industries (2021) One billion trees programme. https://www.mpi.govt.nz/forestry/funding-tree-planting-research/ one-billion-trees-programme. Accessed 17 Aug 2021

Moewaka Barnes H, McCreanor T (2019) Colonisation, hauora and whenua in Aotearoa. J R Soc N Z 49(sup1):19-33

Morgan TKKB (2006) Waiora and cultural identity: water quality assessment using the Mauri model. AlterNative 3(1):42-67

Morgan TKKB, Reid J, Mcmillan OWT, Kingi T, White TT, Young B, Snow V, Laurenson S (2021) Towards best-practice inclusion of cultural indicators in decision making by Indigenous peoples. AlterNative: An Inter J Indigenous Peoples, 11771801211015686

Muru-Lanning M (2012) Māori research collaborations, mātauranga Māori science and the appropriation of water in New Zealand. Anthropol Forum 22(2):151-164. https://doi.org/10.1080/00664 677.2012 .694171

National Policy Statement for Freshwater Management (2020) New Zealand Government, Wellington NZ. https://www.mfe.govt.nz/ publications/fresh-water/national-policy-statement-freshwatermanagement-2020. Accessed 6 Oct 2020

OECD (2017) Environmental Performance Reviews New Zealand 2017 https://www.oecd.org/newzealand/oecd-environmental-perfo 
rmance-reviews-new-zealand-2017-9789264268203-en.htm. Accessed 6 Oct 2020

Parkner T, Page M, Marden M, Marutani T (2007) Gully systems under undisturbed indigenous forest, East Coast region. New Zealand Geomorphol 84(3-4):241-253

Resource Management Act (1991) http://www.legislation.govt.nz/act/ public/1991/0069/latest/DLM230265.html. Accessed 6 Oct 2020

Rhodes D (2001) Rehabilitation of deforested steep slopes on the East Coast of New Zealand's North Island. Unasylva 52(207):21-29

Selby R, Moore P, Mulholland M (2010) Māori and the Environment: Kaitiaki. Huia Publishers, Wellington

Smith LT (2013) Decolonizing methodologies: research and indigenous peoples, 2nd edn. Zed Books, London

Smith LT (2021) Decolonizing methodologies: research and indigenous peoples, Zed Books Ltd

Te Awa Tupua (Whanganui River) Act (2017) https://www.legislation. govt.nz/act/public/2017/0007/latest/whole.html. Accessed 6 Oct 2020

Taylor LB, Fenemor A, Mihinui R, Sayers TA, Porou T, Hikuroa D, Harcourt N, White P, O’Connor M (2020) Ngā Puna Aroha: towards an indigenous-centred freshwater allocation framework for Aotearoa New Zealand. Australas J Water Resour 25(1):27-39. https://doi.org/10.1080/13241583.2020.1792632

Te Kawa Mataaho Public Service Commission (2021) Te whakapakari i te honongai waenga i te Māori me te Karauna: The Māori Crown relationship. https://www.publicservice.govt.nz/our-work/ the-maori-crown-relationship. Accessed 17 Aug 2021
Te Urewera Act (2014) https://www.legislation.govt.nz/act/public/ 2014/0051/latest/whole.html. Accessed 6 Oct 2020

Te Puna Kōkiri, Ministry of Māori Development (2001) He Tirohanga o Kawa ki te Tiriti o Waitangi, Wellington, NZ. https://www.tpk. govt.nz/en/a-matou-mohiotanga/crownmaori-relations/he-tiroh anga-o-kawa-ki-te-tiriti-o-waitangi. Accessed 6 Oct 2020

Tipa G, Teirney L (2003) A cultural health index for streams and waterways: indicators for recognising and expressing Māori values. Wellington: Ministry for the Environment. 72 p. www.mfe. govt.nz/publications/water/cultural-health-index-jun03. Accessed 6 Oct 2020

Tipa G, Welch R (2006) Co-management of natural resources: issues of definition from an indigenous community perspective. J Appl Behav Sci 42(3):373-391

Townsend CR, Tipa G, Teirney LD, Niyogi DK (2004) Development of a tool to facilitate participation of Maori in the management of stream and river health. EcoHealth 1(2):184-195

Waikato-Tainui Te Kauhanganui Inc (2013) Tai tumu, tai pari, tai ao - Waikato-Tainui Environmental Plan. Hamilton: Waikato-Tainui Te Kauhanganui Incorporated

Waitangi Tribunal (2011) Ko Aotearoa tēnei [electronic resource]: a report into claims concerning New Zealand law and policy affecting Māori culture and identity. Wellington: Waitangi Tribunal

Publisher's Note Springer Nature remains neutral with regard to jurisdictional claims in published maps and institutional affiliations. 